\title{
The simple fabrication of nanorods mass production for the dye-sensitized solar cell
}

\author{
Dharmanto $^{1, *}$, Hendi Saryanto ${ }^{2}$, and Darwin Sebayang ${ }^{3}$ \\ ${ }^{1,2}$ Mechanical Engineering Department, Polytechnic of Gajah Tunggal, 15135 Tangerang, Indonesia \\ ${ }^{3}$ Mechanical Engineering Department, Faculty of Engineering, Mercu Buana University, 11650 Jakarta, Indonesia
}

\begin{abstract}
ZnO}$ nanorods were successfully synthesized by the plasma torch with the zinc powder as the source of $\mathrm{ZnO}$. Several testing was conducted to examine the results of $\mathrm{ZnO}$ nanoparticles among others are X-ray fluorescence (XRF), Scanning Electron Microscopy (SEM), and X-ray diffraction (XRD). The results of $\mathrm{ZnO}$ nanorods diameter vary from $87 \mathrm{~nm}$ to $263 \mathrm{~nm}$ which can be seen from SEM images and it is length varies from 300 to $1000 \mathrm{~nm}$. It was found from XRD data that a sharp peak occured at $36.253^{\circ}$. It is indicated a good crystal growth and agreed well with the standard data (JCPDF-ICDD card no.: 36-1451). Effects of electrical current variations of plasma torch of 20, 25, and 30 Amperes on the size of $\mathrm{ZnO}$ nanorods are indicated from aspect ratio $(72.85,87.42$, and $103 \mathrm{~nm})$. The effects of electrical current of plasma torch on the purity of $\mathrm{ZnO}$ were about $95.61 \%, 98.46 \%$, and $96.49 \%$ respectively. The performance of the solar cell at the time with the values of Voc, Jsc, FF, and efficiency are $0.466 \mathrm{~V}, 1.524 \mathrm{~mA} / \mathrm{cm}^{2}, 51.95 \%$, and $0.37 \%$ respectively. $\mathrm{ZnO}$ nanorods were successfully synthesized by the plasma torch with the zinc powder as the source of $\mathrm{ZnO}$.
\end{abstract}

\section{Introduction}

Dye sensitized solar cells (DSSC) is one application of energy harvesters with low operational cost. Zinc oxide with a similar band gap and comparable electron injection process to that of $\mathrm{TiO}_{2}$, has been proven to be one of the most promising alternatives photoelectrode materials for application in DSSC. Compared to $\mathrm{ZnO}$ or $\mathrm{TiO}_{2}$ nanoparticle films, single crystals of these materials exhibit significantly faster electron transport and greater electron mobility. The faster electron transport is a result of the high electron diffusion coefficients, which will provide significant advantages to device performance $[1,2]$.

The greater electron mobility is due to the direction and uninterrupted conduction channel, which can improve the efficiency of charge collection and enable the production of optically thick cells which absorb more incident light $[3,4]$. In spite of the improved charge transport and the larger electron mobility, onedimensional (1D) $\mathrm{ZnO}$ nanowires show a smaller total surface area for nanowire arrays, as compared to the best $\mathrm{TiO}_{2}$ nanoparticle devices, which adsorb less dye per unit thickness of the cell and thus absorb less light and collect less charge. As a result, the energy conversion efficiency of $\mathrm{ZnO}$ nanowire-based DSSC is typically lower [1,5].

To encourage the application of solar cells in real time, various studies have been directed to look for ways to improve the performance of solar cells DSSC. Strategies for reaching the larger currents from solar cells is to simplify and streamline the movement of electrons which of them is to use a semi-conductor single crystalline nanowires, nanofibers, arrays of nanotubes, and core-shell structure [6].

Due to their diverse application in optical, electrical, optoelectronic, photo catalytic, hydrophilic, hydrophobic, pigments, metal compounds, medical ointments and cosmetics, nanometric $\mathrm{ZnO}$ such as nanospheres, nanoplates, nanosheets, nanoboxes, nanomallets, nanotripods, nanobelts, nanosprings, nanorings, nanocages, nanoneedles, nanorods, nanotubes, nanopropellers, nanoflowers and nanowindmills have been the attractive research topics in nano science and technology for few decades [7-18].

Various $\mathrm{ZnO}$ nanostructures have been extensively investigated for DSSC. In the early reports on $\mathrm{ZnO}$-based DSSC, $\mathrm{ZnO}$ nanoparticles were often used as the photoanode prepared by a conventional doctor blade technique [56]. The experimental results of a new solar cell fabricated from an electron-accepting layer of freestanding $\mathrm{ZnO}$ nanowires [57]. The nanowire DSSC is an exciting variety of the most successful of the excitonic photovoltaic devices [58]. As an ordered topology that increases the rate of electron transport, a nanowire electrode may provide a means to improve the quantum efficiency of DSSC in the red region of the spectrum, where their performance is currently limited. Raising the efficiency of the nanowire cell to a competitive level depends on achieving higher dye loadings through an increase in surface area [59].

\footnotetext{
* Corresponding author: dharmanto.mesin@gmail.com
} 
Recently, various techniques have been proposed for $\mathrm{ZnO}$ nanoparticles fabrication. It can be classified into either physical or chemical methods $[19,20]$ such as thermal hydrolysis [21], hydrothermal processing [22], sol-gel [23-24], vapor condensation [25], spray pyrolysis [26-27], pulse laser decomposition [28], laser ablation [29], thermal evaporation [30.31], pulse combustion spray pyrolysis [32], electro-mechanical [33], flame spray pyrolysis [34], direct precipitation [35] and thermal plasma $[36,37,38]$. More specific, the synthesis of $\mathrm{ZnO}$ nanorods has also been performed using various techniques such as hybrid wet chemical route [39], solution process at low temperature [40], physical evaporation [41-43], electrophoretic deposition [44], radio frequency (RF) magnetron sputtering [45], templating against anodic alumina membrane [46] and PTFE capillary tube reaction [47]. Nonetheless, it is important to note that the efficiency and size control still become major research problems in synthesizing $\mathrm{ZnO}$ nanoparticles [38].

\section{Methodology}

$\mathrm{ZnO}$ nanorods were successfully synthesized by the plasma torch reactor, as shown in Fig.1 which was operated at atmospheric pressure and less than $3 \mathrm{KW}$ input plasma power. It can be seen that the reactor composed of five main parts among others is a feeder screw as zinc feeder, a plasma torch reactor as main reaction place, a DC plasma as a plasma power source, a filter and a suction blower. Commercial zinc powders from MERCK made in Germany. It has an average particle size of about $45 \mu \mathrm{m}$ was employed in this study. The impurity of raw material has been checked using XRay Fluorescence (XRF- PANalytical-Minipal QC) giving results of $98.9 \%$ purity of zinc and containing impurities such as $\mathrm{Ca}, \mathrm{Cr}, \mathrm{Fe}$, and $\mathrm{Ni}$.

A screw conveyor fed zinc powder into the plasma torch reactor at the fix rate of $2 \mathrm{~g} / \mathrm{min}$ with gas carrier. These having entered the plasma torch reactor then faced plasma zone, then vaporization and oxidation were experienced by the zinc powders immediately forming $\mathrm{ZnO}$ nanoparticles.

The time elapsed to form $\mathrm{ZnO}$ nanoparticles under this process take about $0.01 \mathrm{~s}$ [36]. The results of vapors from burning process were then dropped to silo, then sucked by blower passed through the filter tube so that $\mathrm{ZnO}$ powders could be seized by filter membrane. Electrical currents inputted to the plasma poles (cathode and anode) were varied from 20, 25, and 30 Ampere .

Several testing was conducted to examine the results of $\mathrm{ZnO}$ nanoparticles among others, are X-ray fluorescence (XRF-PANalytical-Minipal QC), X-ray diffraction (XRD-PHILLIP-XPERT PRO) and Scanning Electron Microscopy (SEM-FEI-Inspect S50), To ensure the purity of synthesized rod-like $\mathrm{ZnO}$ nanoparticles, XRF (PANalytical-Minipal QC) operated at $20 \mathrm{kV}$ was used as qualitative and quantitative elemental analysis.

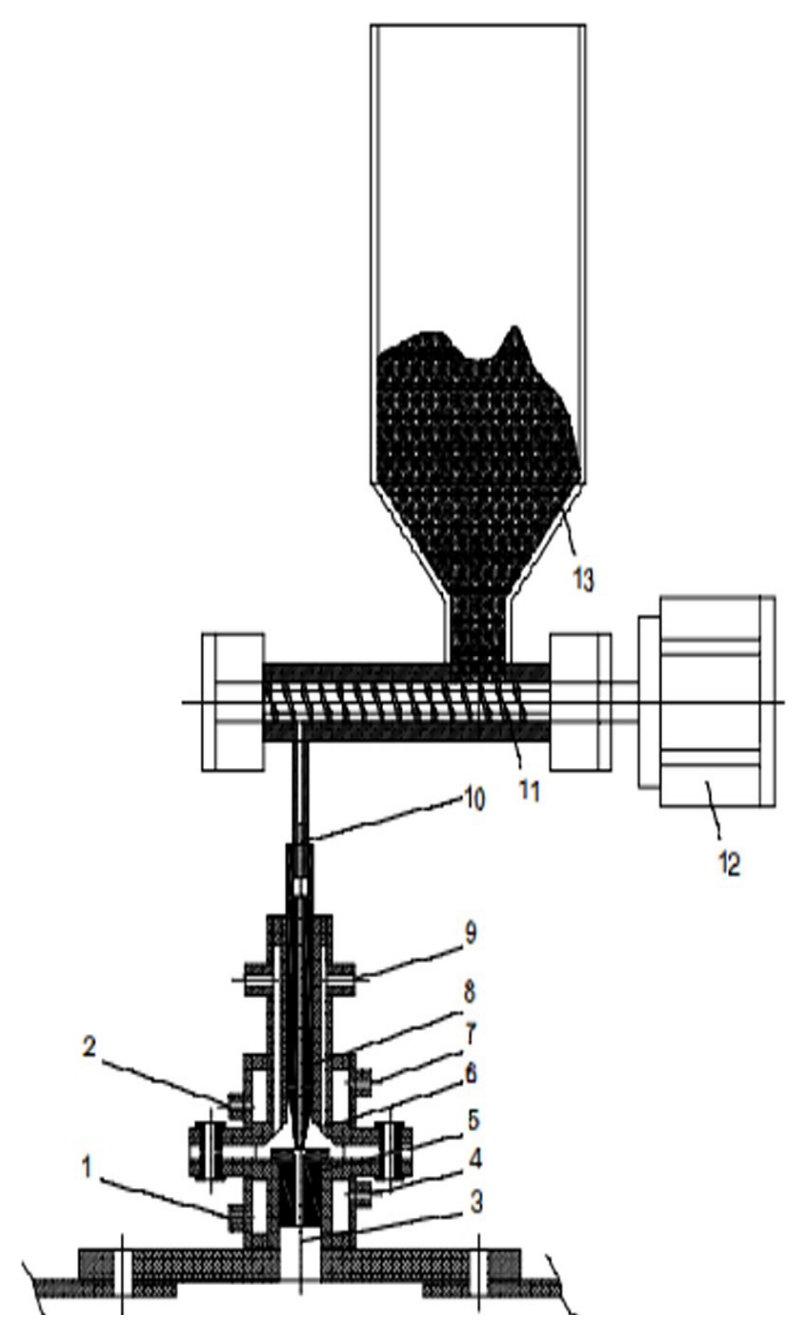

\begin{tabular}{|c|l|c|}
\hline NO & DESCRIPT ION & MATERIAL \\
\hline 1 & WATER INLET & SUS304 \\
\hline 2 & WATER INLET & SUS304 \\
\hline 3 & PLASMA OU TPUT & \\
\hline 4 & WATER OUTLET & SUS304 \\
\hline 5 & BOTTO M G RAPHITE & GRAPHITE \\
\hline 6 & COMPRESSION AIR & SUS304 \\
\hline 7 & WATER OUT LT & SUS304 \\
\hline 8 & TOP GRAPHITE & GRAPHITE \\
\hline 9 & COMPRESSION AIR NLET & SUS304 \\
\hline 10 & ZINC POWDER INLET & SUS304 \\
\hline 11 & FEEDER SCREW & SUS304 \\
\hline 12 & STEPPER MOTOR & \\
\hline 13 & ZINC POWDER SILO & SUS304 \\
\hline
\end{tabular}

Fig. 1. The Simple Plasma Torch Machine Design.

In case of crystallite size and phase identification, an examination of the as-prepared $\mathrm{ZnO}$ nanorods involved X-ray diffraction analysis by the 2-2 $\theta$ method. XRD (PHILLIP-XPERT PRO) was equipped with $\mathrm{Cu} \mathrm{Ka}$ $(\lambda=0.154060 \mathrm{~nm})$ radiation at $40 \mathrm{kV}$ and $30 \mathrm{~mA}$. For each step, the scanning step size and collection time were set at 0.02 and 0.5 respectively. 
Scanning electron microscopy (FEI-Inspect S50) operated at $20 \mathrm{kV}$ was used to capture the morphology of the synthesized $\mathrm{ZnO}$ nanorods.

The DSSC consisted of a conducting glass, the $\mathrm{ZnO}$, dye-absorbing electrode, the electrolyte, and a counterelectrode layer. The fluorine-doped tin oxide (FTO), used as the conducting glass substrate, was prepared using spray pyrolysis [50]. A solution of tin (II) chloride dihydrate (16.12 g, $\mathrm{Cl}_{2} \mathrm{Sn} \cdot 2 \mathrm{H}_{2} \mathrm{O}$, Merck), ammonium fluoride $\left(0.265 \mathrm{~g}, \mathrm{NH}_{2} \mathrm{~F}\right.$, Merck), and ethyl alcohol (100 $\mathrm{ml}, 96 \%$, Merck) of $100 \mathrm{ml}$ was mixed and sprayed on the glass surface, followed by heating at $450^{\circ} \mathrm{C}$ [55]. To prepare the catalytic platinum counter electrode, the FTO glass was first heated at $200^{\circ} \mathrm{C}$. Platinum was then

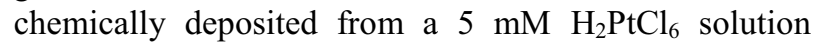
(Merck) onto the FTO glass, followed by heating at $300^{\circ} \mathrm{C}$ and subsequent cooling [51].

The fabrication of the nanorods $\mathrm{ZnO}$ working electrode, a homogenous paste containing nanorods $\mathrm{ZnO}$ semiconductor $(0.5 \mathrm{~g})$ and ethyl alcohol $(0.4 \mathrm{~mL}, 96 \%$, Merck) was prepared. The paste was then cast onto the FTO glass $(1 \mathrm{~cm} \times 3 \mathrm{~cm})$ using the doctor-blade method. For a strong bonding between the $\mathrm{ZnO}$ film nanorods and the FTO glass $[52,53]$, the $\mathrm{ZnO}$ paste-coated FTO glass was sintered at $450^{\circ} \mathrm{C}$ for $2 \mathrm{~h}$ and subsequently cooled. Afterwards, the $\mathrm{ZnO}$ working electrodes were immersed in the respective dye solutions for $24 \mathrm{~h}$ at room temperature, prior to the DSSC assembly $[53,54]$.

The electrolyte solutions for the DSSC were prepared as follows: sodium iodide (3.3 g, 99.9\%, Merck) and acetonitrile $(30 \mathrm{ml})$ were dissolved by stirring for 20 minutes, prior to adding iodine (524 g, 99.9\%, Merck). The stirring was continued for $24 \mathrm{~h}$ to Achieve a homogeneous solution. The electrolyte solution was injected into the assembled DSSC spaced at $50-\mu \mathrm{m}$ intervals and then sealed. [55]

In this research will be testing the IV characterization tests on solar cells DSSC. The testing uses Xenon lamps under illumination by a lamp of $1000 \mathrm{~W} / \mathrm{m}^{2}$ and solar cell characterization test equipment. For characterization testing of solar cells DSSC several parameters such as $\mathrm{J}_{\mathrm{sc}}$ Short Circuit Current, Open Circuit Voltage$\mathrm{V}_{\mathrm{oc}}$, and Fill Factor-FF and Efficiency of solar cell DSSC ( $)$ will be tested. This efficiency value which becomes the main reference in determining the quality of performance of a solar cell.

\section{Results and Discussion}

The diameter of the results of $\mathrm{ZnO}$ nanorods varies from $87 \mathrm{~nm}$ to $263 \mathrm{~nm}$ which can be seen from SEM images with length varies from $300 \mathrm{~nm}$ to $1000 \mathrm{~nm}$. Fig.2, Fig.3, Fig.4 shows the morphology and size of the $\mathrm{ZnO}$ nanorods. The size of $\mathrm{ZnO}$ nanorod range $72 \mathrm{~nm}$ $103 \mathrm{~nm}$. Effects of electrical current variations of plasma torch of 20, 25, and 30 Ampere to the size of $\mathrm{ZnO}$ nanorods are also indicated from the aspect ratio of about $72.85,87.42$, and $103 \mathrm{~nm}$.
Table 1 shows the other effects of electrical current variations of plasma torch to the purity of $\mathrm{ZnO}$ about $95.61 \%, 98.46 \%$, and $96.49 \%$ respectively.

Table 1. Compound effects of electrical current variations of plasma torch of 20, 25, and 30 Amperes to the purity of $\mathrm{ZnO}$

\begin{tabular}{|c|c|c|c|c|c|}
\hline \multirow{2}{*}{ Ampere } & \multicolumn{5}{|c|}{ Compound (\%) } \\
\cline { 2 - 6 } & $\mathbf{Z n O}$ & $\mathbf{C a O}$ & $\mathbf{C r}_{2} \mathbf{O}_{3}$ & $\mathbf{F e}_{2} \mathbf{O}_{3}$ & NiO \\
\hline 20 & 95.61 & 0.24 & 0.11 & 0.15 & 0.082 \\
\hline 25 & 98.46 & 0.14 & 0.098 & 0.16 & 0.086 \\
\hline 30 & 96.49 & 0.55 & 0.13 & 0.19 & 0.13 \\
\hline
\end{tabular}

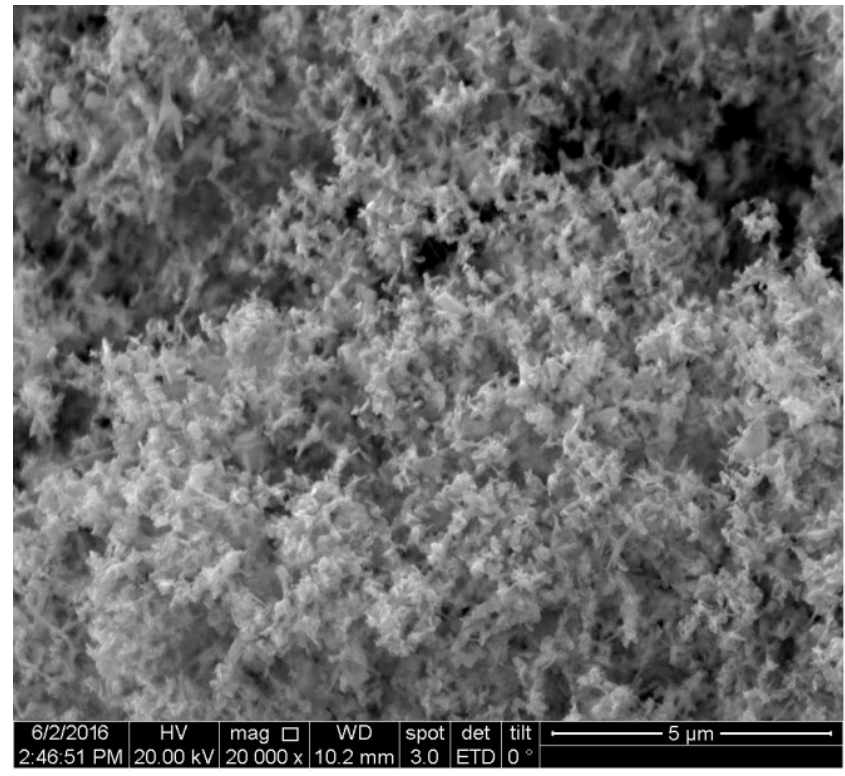

Fig. 2. Photo of SEM ZnO are formed from zinc powder with the 20 ampere plasma torch process.

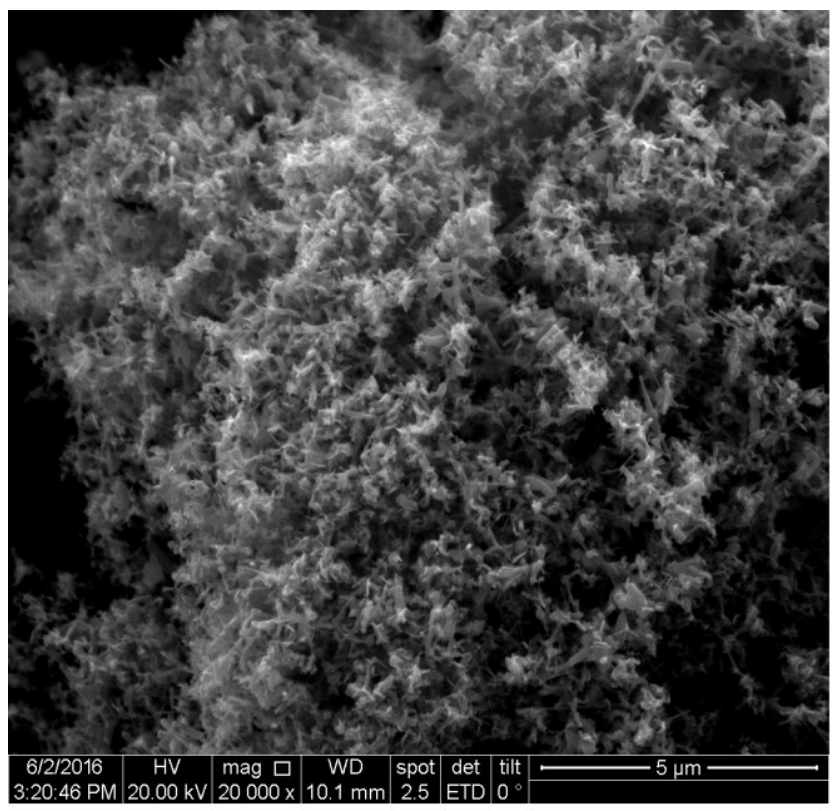

Fig. 3. Photo of SEM ZnO are formed from zinc powder with the 25 ampere plasma torch process. 


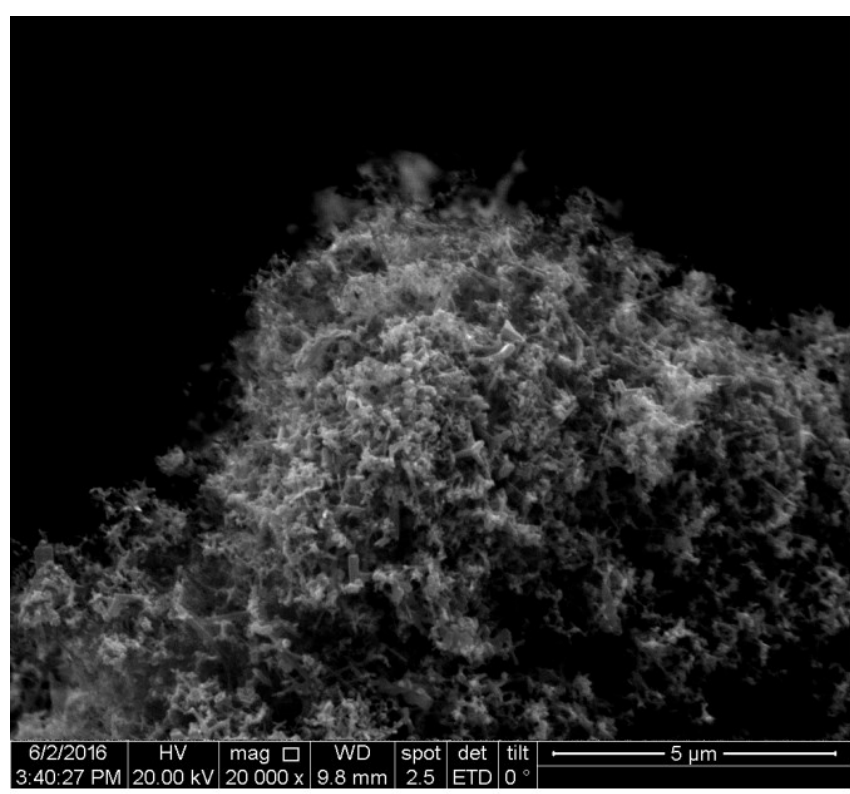

Fig. 4. Photo of SEM $\mathrm{ZnO}$ are formed from zinc powder with the 30 ampere plasma torch process

The XRD pattern of resulted $\mathrm{ZnO}$ nanorods is performed in Fig.5. In this study, each crystalline structure of $\mathrm{ZnO}$ nanorods is a perfect crystal with the growth direction of $c$ axis. Three XRD patterns are indexed as hexagonal wurtzite structure of $\mathrm{ZnO}$ having space group of P63mc (186) with lattice constant sets of $\mathrm{a}, \mathrm{b}=3.24982 \AA$ and $\mathrm{c}=5.20661 \AA$, which is consistent with the values in the database of JCPDF-ICDD card no.: $36-1451$ [49]. Nine peaks appear at $2 \Theta=31.768^{\circ}, 34.421^{\circ}$, $36.253^{\circ}, 47.539^{\circ}, 56.594^{\circ}, 62.856^{\circ}, 66.375^{\circ}, 67.947^{\circ}$, $69.085^{\circ}$, respective to miller indices of $(100),(002),(101)$, (102), (110), (103), (200), (112), and (201).

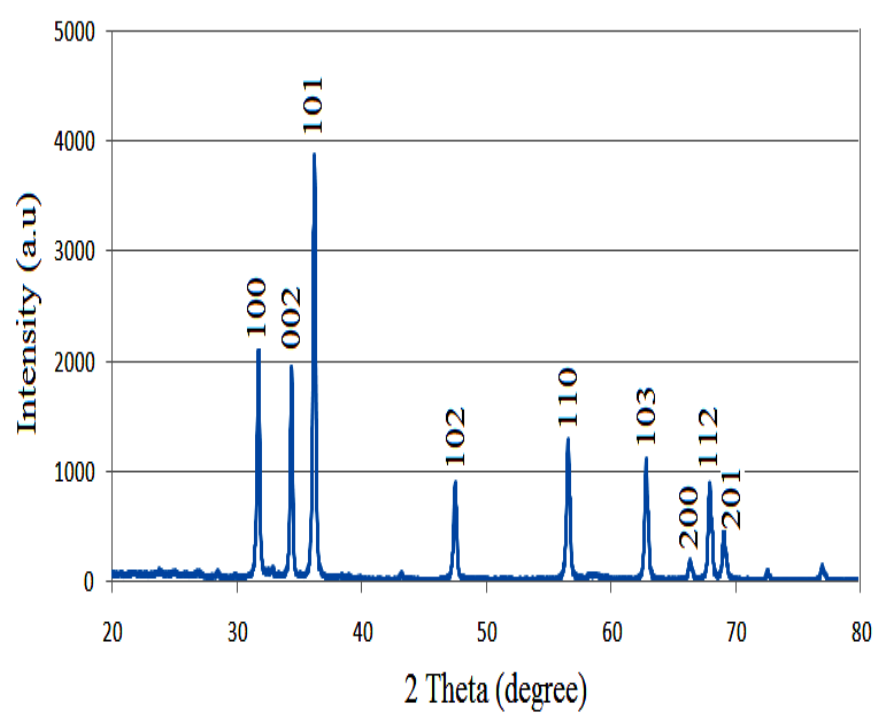

Fig. 5. XRD patterns of $\mathrm{ZnO}$ nanorods

Moreover, the strong and narrow intensity diffraction peaks imply the good crystalline nature and size of the synthesized products. Average nano-crystalline sizes $(D)$ obtained from the broadening of XRD peaks are calculated using Scherer's formula as follows [9]:

$$
D=\frac{0.94 \lambda}{B \cdot \cos \theta}
$$

Where $D$ is the crystal size, $B$ is the broadening from the sample or its full width half medium (FWHM), $\lambda$ is the wave length of X-ray, $\theta$ is the Bragg's angle. Calculation results using Equation (1) are listed in Table II.

Table 2. FWHM and crystalline size of $\mathrm{ZnO}$ nanorods.

\begin{tabular}{|c|c|c|c|}
\hline $\begin{array}{c}\text { Miller } \\
\text { index }\end{array}$ & 2 theta (deg) & FWHM & $\begin{array}{c}\text { Crystalline } \\
\text { size (nm) }\end{array}$ \\
\hline$(100)$ & 31.768 & 0.227 & 31.7406 \\
\hline$(002)$ & 34.421 & 0.191 & 37.9835 \\
\hline$(101)$ & 36.253 & 0.226 & 32.2650 \\
\hline
\end{tabular}

The XRD data shows a sharp peak at $36.253^{\circ}$ which indicates a good crystal growth and agrees well with the standard data (JCPDF-ICDD card no.: 36-1451) [49].

$$
\mathrm{mA}
$$

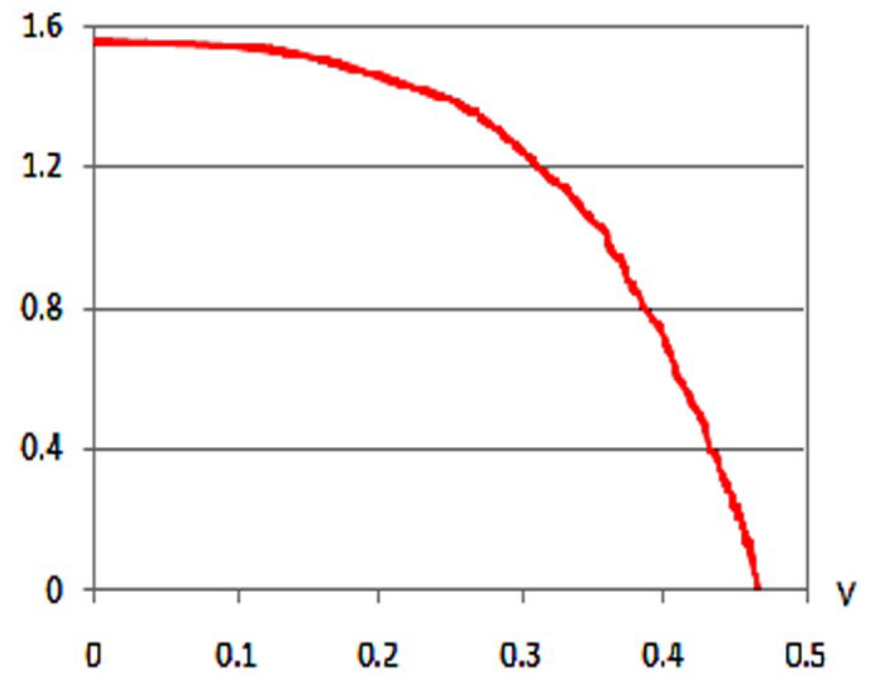

Fig. 6. $J$ - $V$ curves of $\mathrm{ZnO}$ nanorods

In Fig.6, it has shown the performance of the solar cell at the time with the values of Voc, Jsc, FF, and efficiency generated are respectively $0.466 \mathrm{~V}, 1.524$ $\mathrm{mA} / \mathrm{cm}^{2}, 51.95 \%$, and $0.37 \%$.

\section{Conclusion}

$\mathrm{ZnO}$ nanorods were successfully synthesized by the plasma torch with the zinc powder as the source of $\mathrm{ZnO}$. $\mathrm{ZnO}$ nanorods have a high purity $\mathrm{ZnO}$ composition. The plasma torch is a simple fabrication of $\mathrm{ZnO}$ nanorods mass production of dye sensitized solar cell. The advantages of this method are simplicity and potential use for future large scale preparation of $\mathrm{ZnO}$ nanorods, which is useful for many source of energy applications. 


\section{References}

1. M. Law, L. Greene, J. Johnson, R. Saykally, P. Yang, Nat. Mater. 4 455-459, (2005)

2. Y. Hsu, Y. Xi, A. Djuri si, W. Chan, Appl. Phys. Lett. 92 133507, (2008)

3. V. Noack, H. Weller, A. Eychmuller, J. Phys. Chem. B 106 8514-8523, (2002)

4. D. Thomas, J. Lander, J. Chem. Phys. 25 1136-1142, (1956)

5. M. Law, L. Greene, J. Johnson, R. Saykally, P. Yang, Nat. Mater. 4 455-459, (2005)

6. Kim, I.-D., Hong, J.-M., Lee, B.H., Kim, D.Y., dan Jeon, E.-K., Appl. Phys. Lett, 91 (16) (2007)

7. K. Kakiuchi, E. Hosono, T. Kimura, H. Imai, S. Fujihara, J. Sol-Gel Sci. Technol. 39 63-72. (2006)

8. S. Mahmud, M.J. Abdullah, IEEE Conf. Emerging Technol.-Nanoelectron 442-446 (2006)

9. L. Shen, H. Zhang, S. Guo, Mater. Chem. Phys. 114 580-583. (2009)

10. Y. Ding, Z.L. Wang, Micron 40 335-342. (2009)

11. Z.L. Wang, J. Phys. Condens. Mater. 16 R829-R858. (2004)

12. W. Yu, C. Pan, Mater. Chem. Phys. 115 74-79. (2009)

13. M.N.R. Ashfold, R.P. Doherty, N.G. NdiforAngwafor, D.J. Riley, Y. Sun, Thin Solid Films 515 8679-8683. (2007)

14. U. Ozgur, I.A. Ya, C. Liu, A. Teke, M.A. Reshchikov,S. Dogan, V. Avrutin, S.J. Cho, H. Morkoc, J. Appl. Phys. 98 041301. (2005)

15. J. Xie, P. Li, Y. Li, Y. Wang, Y. Wei, Mater. Chem. Phys. 114 943-947. (2009)

16. M.C. Newton, P.A. Warburton, Mater. Today 10 5054. (2007)

17. C. Klingshirn, Phys. Status Solidi B 244 3027-3073. (2007)

18. L. Yu, F. Qu, X. Wu, Applied Surface Science 257 7432-7435. (2011)

19. H.-F. Lin, S.-C. Liao, S.-W. Hung, J. Photochemistry and Photobiology A: Chemistry 174 82-87. (2005)

20. B. Cheng, W. Shi, J. M. Russell-Tanner, L. Zhang, E. T. Samulski, Inorg. Chem. 45 1208-1214. (2006)

21. H.K. Park, D.K. Kim, C.H. Kim, J. Am. Ceram. Soc. 80 743. (1997)

22. S.I. Hirano, Ceram. Bull. 66 1342. (1987)

23. D. Vorkapic, T. Matsoukas, J. Am. Ceram. Soc. 81. 2815. (1998)

24. Y.X. Li, K.J. Klabunde, Chem. Mater. 4 611. (1992)

25. V.R. Palkar, Nanostruct. Mater. 11 369. (1999)

26. C.G. Granqvist, R.A. Burhman, J. Appl. Phys. 47 2200. (1976)

27. T.T. Kodas, Adv. Mater. 6 180. (1989)

28. G.L. Messing, S.C. Zhang, G.V. Jayanthi, J. Am. Ceram. Soc. 76 2707. (1993)

29. J.P. Pollinger, G.I. Messing, J. Aerosol Sci. Technol. 19 217. (1993)

30. R.D. Vispute, V. Talyansky, S. Choopun, R.P. Sharma, T. Venkatesan, M. He, X. Tang, J.B. Halpern, M.G. Spencer, Y.X. Li, L.G. Salanmanca
Riba, A.A. Iliadis, K.A. Jones, Appl. Phys. Lett. 73 348. (1998)

31. M.A. Gondal, Z.H. Yamani, Q.A. Drmosh, A. Rashid, Int. J. of Nanoparticles. 2 no. 1/2/3/4/5/6 119-128. (2009)

32. K. Triphati, M. Husain, N.A. Salah, S.S. Habib, S.M.A. El-Hamidy, N.Z. Zahed, Z.H. Khan, Int. J. of Nanoparticles 2 no. 1/2/3/4/5/6 148-155. (2009)

33. S.G. Hussain, D. Liu, X. Huang, K.M. Sulieman, S.T. Rasool, Int. J. of Nanoparticles 2 no. 1/2/3/4/5/6 443-450. (2009)

34. I.M. Joni, A. Purwanto, F. Iskandar, M. Hazata, K. Okuyama, Chemical Engineering J. 155 433-441. (2009)

35. Y. Hames, Z. Alpaslan, A. Kosemen, S.E. San, Y. Yerli, Solar Energy 84 426-431. (2010)

36. H.-F Lin, S.-C Liao, C.-T Hu, J. Crystal Growth 311 1378-1384. (2009)

37. H.-F. Lin, S.-C. Liao, S.-W. Hung, J. Photochemistry and Photobiology A: Chemistry 174 82-87. (2005)

38. T.S. Ko, S. Yang, H.C. Hsu, C.P. Chu, H.F. Lin, S.C. Liao, T.C. Lu, H.C. Kuo, W.F. Hsieh, S.C. Wang, Materials Sience and Engineering B 134 54-58. (2006)

39. R.N. Gayen, S. Dalui, A. Rajaram, A.K. Pal, Applied Surface Science 255 4902-4906. (2009)

40. H.-S. Choi, M. Vaseem, S.G. Kim, Y.-H. Im, Y.-B. Hahn, J. Solid State Chemistry 189 25-31. (2012)

41. L.-Y. Chen, S.-H. Wu, Y.-T. Yin, J. Phys. Chem. C 113 21572-21576 (2009)

42. D.P. Singh, Sci. Adv. Mater. 2 245-272. (2010)

43. M.E. Fragala, Y. Aleeva, C. Satriano, J. Nanosci. Nanotechnol. 11 8180- 8014. (2011)

44. J. Cui, J. Phys. Chem. C. 112 (2008) 10385-10388.

45. C. Li. G. Fang, J. Li, L. Ai, B. Dong, X. Zhao, J. Phys. Chem. C 112 990-995. (2008)

46. J.-T. Yan, C.-H. Chen, S.-F. Yen, C.-T. Lee, IEEE Photonics Technol. Lett. 22. 146-148. (2010)

47. S. He, Y. Liu, M. Uehara, H. Maeda, Material Science and Engineering B 137 295-298. (2007)

48. T.S. Ko, S. Yang, H.C. Hsu, C.P. Chu, H.F. Lin, S.C. Liao, T.C. Lu, H.C. Kuo, W.F. Hsieh, S.C. Wang, Materials Sience and Engineering B 134 54-58. (2006)

49. R. Verma, B. mantra, Ramphal, A. K. Srivastava, Advanced Materials latters 326 324-333. (2015)

50. A.V. Moholkar, S.M. Pawar, K.Y. Rajpure, C.H. Bhosale, J.H. Kim, Appl. Surf. Sci., 255 9358-9364, (2009)

51. P. Calandra, G. Calogero, A. Sinopoli, P.G. Gucciardi, Int. J. Photoenergy, 2010 1-15, (2010)

52. H. Chang, Y.J. Lo, Sol. Energy, 84 1833-1837, (2010)

53. H. Chang, H.M. Wu, T.L. Chen, K.D. Huang, C.S. Jwo, Y.J. Lo, J. Alloys Compd., 495 606-610, (2010)

54. K. Wongcharee, V. Meeyoo, S. Chavadej, Sol. Energy Mater. Sol. Cells, 91 566-571, (2007)

55. Suyitno,T.J. Saputra, A. Purwanto, Z.Arifin, S13861425(15)00422-9 (2015) 
56. Keis, K.; Bauer, C.; Boschloo, G.; Hagfeldt, A.; Westermark, K.; Rensmob, H. \& Siegbahn, H. J. Photochemistry and Photobiology A: Chemistry, 148, No. 1-3, pp. 57-64, (2002),

57. [Lévy-Clément, C.; Tena-Zaera, R.; Ryan, M. A.; Katty, A. \& Hodes, G. Advanced Materials 17, No.12,pp.1512-1515, ,(2005),

58. Law, M.; Greene, L. E.; Johnson, J. C.; Saykally, R. \& Yang, P. (2005). Nature Materials 4, No. 6, , pp. 455-459, (2005)

59. Law, M.; Greene, L. E.; Radenovic, A.; Kuykendall, T.; Liphardt, J. \& Yang, P. J. Physical Chemistry B110, No. 45, pp. 22652 22663, (2006) 